\title{
Ethics Education for Finance Students Following the GFC
}

\author{
Richard I. Copp and Victor Wong* \\ Griffith University, Australia \\ * The authors have benefited from comments by Joanne Copp, Eugene Clark, Eduardo Roca, and \\ two anonymous referees. All errors and omissions, of course, remain the authors' responsibility.
}

\begin{abstract}
University finance curricula have been criticized in the financial press in the wake of the GFC for ignoring the ethical dimensions of financial decision-making in practice. Many practitioners experience moral dilemmas about whether the broader "public interest" objectives of legal or accounting regulation, for example, should at times be sacrificed in favour of fulfilling an inconsistent upper management objective. Moreover, many propositions in finance are both positive and normative. For example, financial maxima and optima can be discussed only for a given distribution of wealth between relevant parties: shareholder wealth can be maximized, but only subject to a "given" constraint determined by the ethical norms of the society in which the firm operates. Assuming students' sensitivity to ethical issues can be enhanced, ethics should be embedded within finance curricula, together with a final year, capstone course on "Ethical Investing" in the degree.
\end{abstract}

Keywords: ethics, moral philosophy, instrumental, non-instrumental, positive, normative, axiology, cross-disciplinary, student learning.

\section{Introduction}

High profile cases involving business ethics (or a lack of them) have been widely publicized throughout the western world including Australia, New Zealand, the United Kingdom, and the United States. The last decade has seen the collapse, for example, of Enron, WorldCom, Arthur Andersen, AIG, Lehman Brothers, Bear Stearns and Merrill Lynch in the United States; HIH, FAI, Storm Financial, ABC Learning in Australia; RBS, Northern Rock, Lloyds, and Anglo Irish Bank in the United Kingdom; and growing public dissatisfaction with much corporate behavior. ${ }^{1}$ John Kenneth Galbraith has described the contemporary corporate world as analogous to a harlot who, while she dresses very nicely, remains nonetheless a harlot. ${ }^{2}$ Others have attributed much of the Global Financial Crisis (GFC), at its root, to banking institutions losing trust in each other. ${ }^{3}$

1. For similar concerns a generation ago, see e.g. Milton-Smith, J. (1997), "Business Ethics in Australia and New Zealand", Journal of Business Ethics, 16: pp. 1485-1497, at 1486; and Khera, I. P. (2001), "Business Ethics East vs. West: Myths and Realities", Journal of Business Ethics, 30: pp. 29-39, at 29. 
Mutual trust can mark the difference between efficient and inefficient economic processes. ${ }^{4}$ Markets and societies in which participants can trust each other because each observes shared ethical norms run more efficiently than markets and societies that do not. ${ }^{5}$

University finance curricula were criticized in the financial press in the wake of the GFC for ignoring the ethical dimensions of decision making. In economics, from which finance theory is in part derived, ethics is normally treated as a "given", determined with reference to societal norms; ${ }^{6}$ and behaviour in firms and markets can be optimised within the bounds imposed by ethical and other constraints, using second best principles if appropriate. ${ }^{7}$ Pareto optima can be discussed only for a given distribution of wealth; ${ }^{8}$ and much about the revealed axiology and ethical preferences of a corporate community or a wider society can be discerned from its wealth distribution. ${ }^{9}$

There seems little reason why finance curricula should not adopt a similar approach. ${ }^{10}$ Shareholder wealth could still be maximized, but only subject to a "given" constraint determined by the ethical norms of the society in which the corporation operates. By extension, the distribution of wealth between the firm's various stakeholders (e.g. shareholders, debt holders and management ${ }^{11}$ ) could still be determined by equilibrium values of bonding costs, monitoring costs and residual loss, but only subject to a similar "given" ethical constraint, at the limit determined by society (e.g. through regulation and norms of "acceptable" behaviour). ${ }^{12}$

2. Galbraith, J. K. (2004), The Economics of Innocent Fraud: Truth for Our Time, New York: Houghton Mifflin, pp. 15-21.

3. Grayling, A. C. (2010), Thinking of Answers, London: Bloomsbury, pp. 82-84. See also Sen, A. (1995), "Moral Codes and Economic Success", in Brittain, S. and Hamlyn, A. (eds.), Market Capitalism and Moral Values, Aldershot England: Edward Elgar, pp. 23-24.

4. Fukuyama, F. (1995), Trust: The Social Virtues and the Creation of Prosperity: New York, The Free Press; and Donaldson, T. (2001), "The Ethical Wealth of Nations", Journal of Business Ethics, 31: pp. 25-36, at 25; O’Brien, J. (2007), Redesigning Financial Regulation: The Politics of Enforcement, Chichester UK, John Wiley \& Sons, p. 201; and Kapur, B. K. (1999), "Harmonization Between Communitarian Ethics and Market Economics", Journal of Markets and Morality, 2(1): pp. 35-52, at 43.

5. Cf. Bernstein, W. J. (2006), "Corporate Finance and Original Sin", Financial Analysts Journal, 62 (3): pp. 20-23, at 20. See also Statman, M. (2007), "Local Ethics in a Global World", Financial Analysts Journal, 63(3): pp. 32-41, at 40, in which Prof Statman argues that ethics, fairness, trust, and freedom from corruption are all important in financial markets.

6. Wilson, R. (1997), Economics, Ethics, and Religion: Jewish, Christian and Muslim Economic Thought, New York: New York University Press, p. 3.

7. See for example, Little, I. M. D. (1960), A Critique of Welfare Economics, $2^{\text {nd }}$ ed., Oxford: Oxford University Press; Kolsen, H. M. (1968), The Economics of Road-Rail Competition, Brisbane: University of Queensland Press; Mishan, E. J. (1969), Welfare Economics: Ten Introductory Essays, $2^{\text {nd }}$ ed., London: Random House; Mishan, E. J. (1976), Cost Benefit Analysis, New York: Holt Rhinehart \& Winston; and Mishan, E. J. (1997), An Introduction to Normative Economics, Oxford: Oxford University Press.

8. Wilson, R., op. cit., p. 4.

9. Little, I. M. D. (1960), op. cit.; and Little, I. M. D. (2002), Ethics, Economics and Politics: Principles of Public Policy, Oxford: Oxford University Press. 
The structure of this paper is as follows. The nature of ethics is discussed in section 2, while section 3 addresses why it is important to finance students to learn ethics. Sections 4, 5 and 6 respectively investigate whether ethics can be taught; and, if so, how and when it is best learned. Section 7 sets out the conclusions of the paper.

\section{The Nature of Ethics}

As characterized in this paper, there are a range of ethical systems or approaches. Moral philosophy would normally point not to one solution to an ethical problem, but to a range of potential solutions, the ranking of which depends on the particular axiology of moral values. While the resolution of ethical solutions may be uncertain at the margin, moral philosophy does recognise certain solutions as plainly "wrong", and others as ethically superior. And within these morally "right" solutions, criteria based in moral philosophy can, within sometimes broad limits, be applied to determine whether one "right" solution is morally superior to another. ${ }^{13}$ Even for post-modernists, there can be a "truth", albeit one which "is always contingent, and which conceals and suppresses other truths." ${ }^{14}$ Postmodernists make a valid point. ${ }^{15}$

Ethics are commonly categorised as either instrumental or noninstrumental. ${ }^{16}$ Instrumental ethics are the means or instruments by which a

10. Not everybody would agree. For example, see Dobson, J. (1993), "The Role of Ethics in Finance", Financial Analysts Journal, 49(6): pp. 57-61, at 57, 60. In short, Dobson is appealing to the financial community to adopt ethics for its own sake, because it is the "right thing to do", not because it is imposed on them as a constraint. Few moral ethicists would disagree with this ideal, but until such a utopia emerges, it is probably best to acknowledge human imperfection and, for the purposes of financial analysis, treat ethical norms as constraints on behaviour.

11. This list could easily be extended to include other "stakeholders" in the firm such as customers, non-management employees, regulatory bodies acting on behalf of the wider community, and others: see for example, Hill, J. (1998), "Public Beginnings, Private Ends - Should Corporate Law Privilege the Interests of Shareholders", Australian Journal of Corporate Law, 9: 21; Wood, D. (2002), “Whom Should Business Serve?", Australian Journal of Corporate Law, 14: 266; and the literature cited therein. However, for the sake of simplicity (and because many corporate finance courses do not emphasize these wider stakeholders when teaching financial analysis), this paper will focus on the primary stakeholders in the firm: equity holders, debt holders and management. Cf. Jensen, M. C. and Meckling, W. (1976), "Theory of the Firm: Managerial Behaviour, Agency Costs, and Ownership Structure," Journal of Financial Economics, pp. 305-360; and Watts, R. L. and Zimmerman, J. L. (1978), "Towards a Positive Theory of the Determination of Accounting Standards", The Accounting Review, pp. 112-134.

12. As Prof. Little points out, it is such distributional questions that are often the important ones: see Little, I. M. D. (2002), op. cit., pp. 24, 123-124, 132, and 151; and Arrow, K. J. (1950), “A Difficulty in the Concept of Social Welfare", Journal of Political Economy, 58(4): pp. 328346.

13. See, for example, Kraut, R. (2007), What Is Good and Why: The Ethics of Well-Being, Cambridge, Mass.: Harvard University Press; and Hartman R. C. (1967), The Structure of Value: Foundations of Scientific Axiology, Carbondale, Il.: Southern llinois University Press. 
particular set of objectives are expected to be achieved. They are not the ends (or objectives) in themselves. For example, traffic rules are the means or instruments by which the particular objective (e.g. road safety) or objectives are expected to be achieved. ${ }^{17}$

Non-instrumental ethics are viewed as having intrinsic value as ends in themselves, rather than as a means to some other end (or objective). For example, many people tell the truth because they view it as the "right" thing to do-and an end in itself-not as a means to some other end. In an ideal world, noninstrumental ethics trump instrumental ethics, in the sense that - assuming the ends or objectives are moral - the former are generally seen as morally superior to the latter. The ranking of ends, objectives, or virtues depends on (ethical) value theory or axiology. ${ }^{18}$ For instance, in many contexts, honesty has an ethical value that generally trumps, or is morally superior to, that of zeal.

Generally accepted accounting principles or rules are instrumental, in the sense that they are designed to achieve an objective - namely the summary of a true and fair view of the firm's operations and financial position, in the belief that this will narrow information asymmetry between the insiders to the firm and its external stakeholders in the public interest. A moral dilemma in which accountants frequently find themselves is whether this broader "public interest" objective of the accounting rules should at times be sacrificed in favour of fulfilling an inconsistent corporate or management objective.

Finance graduates face comparable ethical dilemmas. For example, most have historically been taught during their studies that the objective of the firm is to maximise shareholder wealth (with little or no reference to ethical objectives); they will, however, later read - and, by their employment contract, be obliged to comply with - the lofty "higher purpose" goals in their company's ethical Mission Statement. A non-instrumental ethical approach would require such graduates to behave primarily with reference to ethical objectives, and only then seek to maximize shareholder wealth. ${ }^{19}$

14. Leiboff, M. and Thomas, M. (2009), Legal Theories: Contexts and Practices, Sydney: Law Book Co., p. 382.

15. Cf. Little, I. M. D. (2002), op. cit., p. xvi.

16. See for example, Quinn, D. P. and Jones, T. M. (1995), "An Agent Morality View of Business Policy”, The Academy of Management Review, 20(1): pp. 22-42.

17. For a good summary of instrumental ethics and its implications for economics, see Hausman, D. M. and McPherson, M. S. (1993), "Taking Ethics Seriously: Economics and Contemporary Moral Philosophy", Journal of Economic Literature, 31: pp. 671-731, at 684-686.

18. See for example, Hart, S. L. (1971), "Axiology: Theory of Values", Philosophy and Phenomenological Research, 32(1): pp. 29-41, at 29.

19. Cf. Quinn, D. P. and Jones, T. M. (1995), op. cit.; Moore, G. (1999), "Corporate Moral Agency: Review and Implications", Journal of Business Ethics, 21: pp. 329-343; and the literature reviewed therein. 


\section{Why Learn Ethics in Finance?}

However, despite such stoic attempts to appear resolutely positivist, ${ }^{20}$ the boundary between positive and normative is seldom precise. ${ }^{21}$ Facts can be heavily value-laden. As noted earlier, economics has already been down this path. $^{22}$ Likewise many propositions in finance are jointly descriptive and valueladen. For example, in the context of the GFC, when we speak to students of Ponzi schemes or security issues that generate wealth transfers between classes of security holders, it is natural for people to have some sympathy, based on grounds of morality, for stakeholders whose wealth has been expropriated. When we speak of contagion spreading between firms, markets and even countries, it is natural for people to feel that it is somehow unfair or inequitable for others to be adversely affected through no fault of their own. As suggested by the term "moral hazard", the government bailouts of financially distressed corporations considered "too big to fail" has ethical implications, not only for the taxpayers who fund them but the firms (including Wall Street firms) who are their beneficiaries. Similarly, financiers' exploitation of information asymmetries between bankers and small investors through the use of confusing terms such as "negative equity" and "bridging equity" in prospectuses has ethical implications for both.

Against this background, there are a number of reasons why finance students should learn about ethics in their curricula. ${ }^{23}$ First, as already noted, many propositions in finance are jointly positive and normative in character, and should recognisable by students as such. Second, ethics influence agents' choices and conduct, and therefore financial and economic outcomes; and a study of ethics may well influence students' choices and behaviours when faced with moral dilemmas in the future. ${ }^{24}$

Third, the efficient functioning of markets must take place within the context of the law, which is predicated on an axiology of ethical values such as minority shareholder protection, the unfairness of insider trading, and the like. In this sense, law is instrumental ethics in action. ${ }^{25}$ Similarly, the regulation of financial markets, firms and institutions is based in the ethical values of the relevant

20. See for instance, Shefrin, H. and Statman, M., in Ang, J. S. (1993), "On Financial Ethics", Financial Management, 22(3): pp. 32-59, at 51-52.

21. Little, I. M. D. (2002), op. cit., p. Xi; and Dubin, R., (1978), Theory Building, $2^{\text {nd }}$ ed., New York: Free Press.

22. Robbins, L. (1938), "Interpersonal Comparisons of Utility: A Comment”, Economic Journal, 48(192): pp. 640-641; and Little, I. M. D. (2002), op. cit., p. 140.

23. Cf. Hausman, D. M. and McPherson, M. S. (1993), op. cit., p. 673, albeit in the context of economics and ethics.

24. Loeb, S. E. (1988), "Teaching Students Accounting Ethics: Some Crucial Issues", Issues in Accounting Education, Fall, pp. 316-329.

25. Cf. Birks, P. (ed) (1993), Examining the law School Syllabus: Beyond the Core, Oxford: Oxford University Press, p. 9. 
society, and an understanding of market processes in practice requires an understanding of ethical (and legal) principles. ${ }^{26}$

Fourth, to the extent that finance and accounting students may be uncomfortable with the uncertainties of ethical dilemmas, a study of ethics prepares finance students for the uncertainties inherent in business life. ${ }^{27}$ Fifth, enhanced sensitivity to ethical issues arguably confers advantages not just on individuals, but ultimately collectively, on nations. ${ }^{28}$ Sixth, maximising shareholder wealth and the pursuit of ethical outcomes are not necessarily antithetical. ${ }^{29}$ Ethical behaviour can, under certain conditions, be viewed as a prerequisite to the attainment of long term corporate objectives, with ethical behaviour of individuals within the corporation best viewed as an organisational asset. $^{30}$

\section{Can Ethics Be Taught?}

Almost 2,500 years ago, the Athenian philosopher Socrates ${ }^{31}$ took the view that a sense of ethics could be "awakened" in every person, though not "taught" in the sense of traditional lecturing. To achieve this, Socrates used a dialectical method in which he, professing ignorance, posed a variety of moral dilemmas to his audience, who did their best to answer them through a process of being asked to refine their definitions and the conditions under which their argument was supportable.

This Socratic process is designed to enhance students' sensitivity to moral issues, and improve their skills in moral reasoning and critical thinking, through participation in the Socratic dialogue itself and an examination of case studies designed to highlight particular ethical issues. Empirical results suggest that this type of training does enhance students' ethical reasoning skills, although it is generally limited to universities, with few companies providing such training to employees. $^{32}$

26. Furthermore, regulators are drawn from the ranks of university graduates and need to see the "bigger picture".

27. Loeb, S. in Ang, J. S. (1993), op. cit., p. 54; and Hausman, D. M. and McPherson, M. S. (1993), op. cit., p. 702.

28. Donaldson, T. (2001), op. cit., pp. 25-26.

29. Werner, S. B. (1992), "The Movement for Reforming American Business Ethics: A TwentyYear Perspective", Journal of Business Ethics, 11(1): pp. 61-70, at 61-62.

30. Werner, S. B. (1992), op. cit., pp. 65-66. The veracity of the fifth and sixth reasons set out here is a topic best left for another paper.

31. See for example, Plato (c. 310 BC), Early Socratic Dialogues, trans. by Saunders, T. (ed), London: Penguin, 2005; Aristophanes (c. 400 BC), The Clouds, trans. by Mitchell, T. (1956), Grolier Classics, New York: Grolier, pp. 473-571; Xenophon (c. 370 BC), Memorabilia: Recollections of Socrates, and Socrates' Defense Before the Jury, trans. by Benjamin, A. S., (1965), Indianapolis: Bobbs-Merrill; Watson, P. (2005), Ideas: A History From Fire to Freud, London: Phoenix, Ch. 6; and Russell, B. (1945), A History of Western Philosophy, New York: Simon \& Shuster. 


\section{How Is Ethics Best Learned in Finance?}

There are plainly a number of potential alternative approaches to teaching moral ethics in finance curricula. One way, using an instrumental-ethical approach, would be to expose students to some of the quasi-legalistic aspects of corporate governance, highlight the importance of corporate culture, and encourage students to think about what an ethical corporate culture might look like in particular contexts. ${ }^{33}$

A second way of approaching ethics education in finance could be to emphasise that, over the long run, markets and societies function more efficiently and effectively if all participants share the same or sufficiently similar ethical values. ${ }^{34}$ This approach would have limited utility for some students, given the propensity of some individuals and firms operating within markets and societies to profit, sometimes hugely, in the short run by engaging in unethical conduct.

A third approach might be to seek to characterise ethical notions such as "fairness" by reference to other finance concepts with which students are familiar, such as assumptions of perfect markets. ${ }^{35}$ For example, Shefrin and Statman argue that "fairness" is a claim to entitlements, including freedom from coercion; freedom from misrepresentation and deliberate misinformation; equal access to information; minimum competency in skills such as financial analysis; efficient prices and a "fair and orderly market"; and equal bargaining in negotiations. ${ }^{36}$ While this approach might have some pedagogical value for finance students, it is nonetheless very limited from the perspective of moral philosophy.

A fourth, somewhat related approach - consistent with mainstream finance theory-would be to evaluate ethical problems by analyzing differential bargaining power; information asymmetries; externalities and free riding opportunities; and addressing concerns about distributive justice ${ }^{37}$ and perhaps even paternalism. ${ }^{38}$ Even so, ethical judgements must still be made, and it is on these that financial economists have little original to say.

32. Delaney, J. T. and Sockell, D. (1992), "Do Company Ethics Training Programs Make a Difference? An Empirical Analysis", Journal of Business Ethics, 11(9): pp. 719-727.

33. Cf. Dobson, J. in Ang, J. S. (1993), op. cit., p. 50.

34. Cf. Kapur, B. K. (1999), op. cit., pp. 35, and 46-47.

35. See Copeland, T. E., Weston, J. F. and Shastri, K. (2005), Financial Theory and Corporate Policy, $4^{\text {th }}$ ed, New York: Pearson Addison Wesley, pp. 353-354.

36. Shefrin, H. and Statman, M., in Ang, J. S., op. cit., pp. 48-49.

37. Distributive justice deals with rights to a fair distribution of resources among stakeholders in society. See for example, Rawls, J. (2001), Justice as Fairness: A Restatement, Cambridge MA: Belknap Press of Harvard University Press; and Rawls, J. (1999), A Theory of Justice, Cambridge MA: Belknap Press of Harvard University Press. In terms of evaluating the "distributive justice" of alternative arrangements from a utilitarian perspective, see Kaldor, N. (1939), "Welfare Propositions in Economics and Interpersonal Comparisons of Utility", The Economic Journal, 49(195): pp. 549-552; Hicks, J. (1939), "The Foundations of Welfare Economics", The Economic Journal, 49(196): 696-712; Scitovsky, T. (1941), “A Note on Welfare Propositions in Economics", Review of Economic Studies, 9(1): pp. 77-88; and Little, I. M. D. (1960), op. cit. 
Probably the most prudent way to introduce ethical judgements into financial analysis would be to still pursue the financial objective- - e.g. seek to maximise value or shareholder wealth, or optimise a queuing problem, for example-but subject to a "given" ethical constraint as described earlier. Students in a classroom setting could be asked either, using a non-instrumental approach, what the "right thing to do would be" in particular circumstances and why; or, adopting a minimalist instrumental approach, what the law requires of relevant stakeholders in the circumstances. Both approaches would produce constraints on relevant asset values, which could then be maximised or optimised as appropriate. ${ }^{39}$

Pedagogically, this approach could allow students to recognize the inherent causes and indicia of unethical practice; how inconsistency of values, inability to distinguish between power and authority, and a preoccupation with self-interest can lead to diminished trust between stakeholders; and how these issues might best be addressed, given corporate and wider societal objectives.

\subsection{Structuring the Degree Program}

However it is done, adding ethical content into curricula could potentially "crowd out" other substantive finance topics. ${ }^{40}$ But if faculty have a genuine commitment to enhance finance student learning outcomes through an appreciation of ethics, class contact time could be managed to incorporate an ethical component without significantly sacrificing key topics. For example, each tutorial could include a discussion question which raises an ethical dilemma for students that relates to the substantive finance topic at hand. Of course, if staff and students do have excess teaching and learning capacity, this ceases to be a problem.

There are at least three ways of organizing a finance degree program to incorporate ethics into curricula. One way would be to introduce a stand-alone course, or a six-week stand-alone module, on business ethics into a core finance

38. For example, in the sense of evaluating the (social) cost-benefit payoff of measures aimed at assisting the vulnerable, such as. social security, compulsory superannuation, 'cooling off' periods, or investor protection measures in corporations legislation such as those dealing with minority shareholder rights.

39. As an alternative, it would admittedly be possible to emphasize a virtue-based ethics which emphasizes moral "excellence" as a corporate objective, rather than view ethics as a constraint on behavior: cf. Dobson, J. in Ang, J. S., op. cit., pp. 49-50. However, the latter is not necessarily pedagogically undesirable, insofar as it would allow students to recognize the tensions between profits and moral behavior, and the fact that not all corporations strive for moral "excellence".

40. Dobson, J. in Ang, J. S., op. cit., p. 65; Loeb, S. E. (1988), op cit., pp. 323, 326; May, W. F. (1980), "Professional Ethics: Setting, Terrain, and Teacher", in Callahan, D. and Bok, S. (eds.)(1980), Ethics Teaching in Higher Education, New York: Plenum Press, pp. 207-208; and Langenderfer, H. Q. and Rockness, J. W. (1989), "Integrating Ethics in to the Accounting Curriculum: Issues, Problems, and Solutions", Issues in Accounting Education, pp. 58-69, at 64. 
program. This may bear little or no relation to the substantive content of the remainder of the course (or other finance courses for that matter), but it could have the advantage of being less resource-intensive, insofar as it could involve only limited staff (or philosophy faculty who may be under-utilised as a teaching resource). However, it is likely to foster a very surface, "consumerist" knowledge of ethics, rather than an in-depth understanding of relevant issues.

A second way would be to embed ethics in all, or a substantial number of, core finance courses. This would appear preferable to the first approach, ${ }^{41}$ and would avoid the issue of whether to place a stand-alone ethics course at the commencement, middle or closing stages of a finance degree program. ${ }^{42}$ Nevertheless, it would normally require a number of teaching staff who are well versed in moral philosophy, and these skills may need to be outsourced or a teamteaching approach adopted with both finance and philosophy staff.

A third way to incorporate ethics in finance curricula would be to embed it in a number of finance courses throughout the degree, but in addition require students to complete a final year course that draws together the various strands of ethical and financial theory that students have learnt throughout their degree.

\subsection{Case Example: A Course on Ethical, Sustainable Investment}

One such course could expose students to so-called ethical investing as the British call it, or socially responsible investing (as North Americans term it). This involves selecting or managing investments with the aim of maximizing investor returns for given risk, but subject to social, environmental and ethical constraints. It is entirely consistent with the approach advocated in this paper. Social constraints include seeking to foster human capital and enhancing worker rights. Environmental constraints include goals of minimizing pollution and the carbon footprint, conservation of non-renewable resources, and preservation of valued ecosystems. Ethical constraints include objectives to eradicate human rights abuses; product testing on animals; or to withdraw any perceived tacit support for oppressive political regimes. ${ }^{43}$

Griffith University in Queensland, Australia has, in keeping with its charter, actively sought to incorporate ethical investment into its finance courses. One example of such a course is "Sustainable Investing", taken by undergraduate students as a "capstone" unit during the last year of their degree. The course

41. Dobson, J. in Ang, J. S., op. cit., p. 52.

42. Loeb, S. E. (1988), op. cit., p. 323.; and Dobson, J. in Ang, J. S., op. cit., p. 54.

43. See for example, Copp, R. I., Kremer, M. L., and Roca, E. (2010), "Socially Responsible Investment in Market Downturns: Implications for the Fiduciary Responsibilities of Investment Fund Trustees”, Griffith Law Review, 19(1): pp. 86-105; and Copp, R. I., Kremer, M. L., and Roca, E. (2010), "Should Funds Invest in Socially Responsible Investments During Downturns? Financial and Legal Implications of the Fund Manager's Dilemma", Accounting Research Journal, 23(3): pp. 254-266. 
focuses on defining sustainable investment and financing; the valuation of financial risk within a sustainability context; the role of stakeholders in ethical investing and financing; the performance of ethical investment funds; the impacts of climate change; carbon and alternative energy markets (Griffith University has its own Financial Trading Room in which students can access live trading data); and the evolution of ethical investment and sustainable finance. As there is no appropriate textbook for the course at this stage, most of the required reading is based on scholarly journal articles from the sustainable finance and ethical investment literature.

The course evolves with developments in the markets, and remains an integral part of the ethical education of finance graduates from Griffith University. As the world focuses on ethical, sustainable investment in the wake of the GFC and mounting evidence of climate change, the course represents a real opportunity to embed ethical values and skills in finance graduates from one of Australia's most innovative universities.

\section{When is Ethics Best Learned?}

If ethical reasoning can be learned, the issue arises as to when ethics is best learned by students. While some psychologists assume that moral growth tends to be correlated with a person's age, ${ }^{44}$ others suggest that moral development is independent of age. ${ }^{45}$

Students do probably need to be taught something about ethics before they engage in case studies, if maximum benefit is to be achieved from a study of ethics; but ethics should ideally be learned throughout the curriculum, provided sufficient resources made available to enable this. ${ }^{46}$

44. See for example, Erickson, E. (1963), "Eight Stages of Man”, in Childhood and Society, $2^{\text {nd }}$ ed., New York: WW Norton; Gould, R. L. (1978), Transformations: Growth and Change In Adult Life, New York: Simon \& Schuster; Levinson, D. (1978), The Seasons of a Man's Life, New York: Knopf.

45. They argue that most people seek to please (or avoid community opprobrium) by conforming to their community's ethical norms and rules for the sake of social harmony. According to such scholars, relatively few people question the appropriateness of the law and seek law reform where the law conflicts with their ethical principles. See for instance, Kolhlberg, L. (1981), Essays on Moral Development, Vol. 1: The Philosophy of Moral Development, San Francisco: Harper \& Row, pp. 101-189; and Kohlberg, L. and Power C. (1981), "Moral Development, Religious Thinking, and the Question of a Seventh Stage", Zygon, 16(3): pp. 203-259.

46. See Ruland, R. G. in Ang, J. S. (1993), op. cit., p. 52; Loeb, S. E. (1988), op. cit., p. 323; and Loeb, S. E. in Ang, J. S. (1993), p. 54. 


\subsection{Who Should Teach Ethics?}

At least in the early years of seeking to include ethics in the finance curriculum, team teaching using a combination of finance academics and trained ethicists would appear to offer the best solution to the problem of integrating the two disciplines in the classroom. ${ }^{47}$

Once the team teaching format becomes more established in the finance curriculum, finance and philosophy scholars could combine resources to produce textbooks and other educational materials that utilise meaningful case studiese.g. based on the GFC experience, or on the growing literature on ethical investment-for use throughout the curriculum.

\section{Conclusions}

The interest in ethics and ethics education may well be countercyclical. It is frequently observed that investors have a higher tolerance for immoral or unethical behaviour (e.g. by management) and less desire for legislative or regulatory protection during market booms; and precisely the converse during market downturns such as the recent GFC. ${ }^{48}$

Currently, the world economy is generally languishing in the wake of the GFC. It could be tempting for many finance faculties considering whether to introduce ethics training into their curricula to do nothing, and simply wait until the market recovers and community interest in ethics education wanes. That would appear, however, to be a manifestly wasted opportunity. And in any event, a financial economics that "is engaged actively and self-critically with the moral aspects of its subject matter cannot help but be more interesting, more illuminating, and ultimately more useful than one that tries not to be."49

47. Cf. Loeb, S. E. (1988), op. cit., pp. 324-326; and Mayer-Sommer, A. P. and Loeb, S. E. (1981), "Fostering More Successful Professional Socialisation Among Accounting Students", Accounting Review, January, pp. 125-136 at 129-130.

48. Shefrin, H. and Statman, M., in Ang, J. S. (1993), op. cit., pp. 51-52; and Noe, T. H. and Rebello, M. J. (1994), "The Dynamics of Business Ethics and Economic Activity", The American Economic Review, 84(3): pp. 531-547, at 543-544.

49. Hausman, D. M. and McPherson, M. S. (1993), op. cit., p. 723. 
